\title{
ARTICLES
}

\section{A STUDY TO ASSESS THE EFFECT OF STRUCTURED TEACHING PROGRAM RELATED TO IMPORTANCE OF ORGAN DONATION AMONG ADULTS OF LUCKNOW CITY}

Mrs. Sheela Rajeev Tiwari

Principal, Bora Institute of Allied health Sciences, Lucknow, Uttar Pradesh, India. DOI: http://doi.org/10.47211/idcij.2020.v07iws02.011

\begin{abstract}
Organ donation is the process when a person allows an organ of their own to be removed and transplanted to another person, legally, either by consent while the donor is alive or dead with the consent of the next of kin. Transplantation is necessary because the recipient's organ has failed or has been damaged by disease or injury. On an average 20 people, die every day from lack of available organs for transplant. One deceased donor can save up to eight lives through organ donation and can save and enhance more than 100 lives through the lifesaving and healing gift of tissue donation. Aim of the study: There is a large gap between the numbers of registered donors compared to those awaiting organ donations on a global level the researcher felt the need to educate the people on importance of organ donation. An evaluative one group pre-test post-test was conducted to assess the effect of structured teaching programme on importance of organ donation among 100 samples of selected areas of Lucknow city. The teaching programme covered areas like Awareness, facts and Misconceptions about organ donation. The procedure of organ donation and organisations working for organ donation were also discussed. The data analysis was done using descriptive and inferential statistics. The mean of pre-test level of knowledge was 6.71with a standard deviation of 3.642 .The mean of post-test level of knowledge was 19.05 with a standard deviation of .757.Calculated $t$ value was- 29.967 and $P$ value is .001 which was greater than the table value at 0.05 level of significance. There is a significant increase in knowledge after the administration of teaching shows that teaching was effective in improving the knowledge on importance of organ donation.
\end{abstract}

Key Words: Structured teaching programme, Organ donation.

ABOUT AUTHOR:

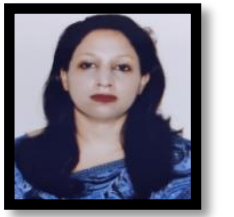

Author, Mrs. Sheela Rajeev Tiwari is the Principal of Bora Institute of Allied Health Science in Lucknow, Uttar Pradesh, India. 


\section{INTRODUCTION}

Organ donation is the process when a person allows an organ of their own to be removed and transplanted to another person, legally, either by consent while the donor is alive or dead with the consent of the next of kin. Transplantation is necessary because the recipient's organ has failed or has been damaged by disease or injury.

As of February 2, 2019, there were 120,000 people waiting for life-saving organ transplants in the United States $^{(1)}$. Of these, 74,897 people were active candidates waiting for a donor. While views of organ donation are positive, there is a large gap between the numbers of registered donors compared to those awaiting organ donations on a global level. ${ }^{(3)}$

To increase the number of organ donors, especially among underrepresented populations, current approaches include the use of optimized social network interventions, exposing tailored educational content about organ donation to target social media users.

In 2017 Spain had the highest donor rate in the world at 46.9 per million people, followed by Portugal (34.0 per million), Belgium (33.6 per million), Croatia (33.0 per million) and the US (32.0 per million). ${ }^{\text {(2) }}$

India has a fairly well developed corneal donation programme; however, donation after brain death has been relatively slow to take off. Most of the transplants done in India are living related or unrelated transplants. To curb organ commerce and promote donation after brain death the government enacted a law called "The Transplantation of Human Organs Act" in 1994 that brought about a significant change in the organ donation and transplantation scene in India. Many Indian states have adopted the law and in 2011 further amendment of the law took place. Despite the law there have been stray instances of organ trade in India and these have been widely reported in the press. This resulted in the amendment of the law further in 2011. Deceased donation after brain death have slowly started happening in India and 2012 was the best year for the programme. As per the Indian Transplant News Letter of the MOHAN Foundation the organ donation rate per million populations Tamil Nadu is with 1.15, Punjab - 0.43, Kerala - 0.36 Guiarat-0.30, Delhi- 0.29, Karnataka0.28, Maharashtra-0, 26, Andhra Pradesh-0.15. Total in India 0.16

The year 2013 has been the best yet for deceased organ donation in India. A total of 845 organs were retrieved from 310 multi-organ donors resulting in a national organ donation rate of 0.26 per million populations.

In the year 2000 through the efforts of an NGO called MOHAN Foundation state of Tamil Nadu started an organ sharing network between a few hospitals. This NGO also set up similar sharing network in the state of Andhra Pradesh and these two states were at the forefront of deceased donation and transplantation programme for many years. As a result, retrieval of 1033 organs and tissues were facilitated in these two states by the NGO. Similar sharing networks came up in the states of Maharashtra and Karnataka; however, the numbers of deceased donation happening in these states were not sufficient to make much impact. In 2008, the Government of Tamil Nadu put together government orders laying down procedures and guidelines for deceased organ donation and transplantation in the state. ${ }^{(4)}$ These brought in almost thirty hospitals in the programme and has resulted in significant increase in the donation rate in the state. With an organ donation rate of 1.15 per million populations, Tamil Nadu is the leader in deceased organ donation in the country. The small success of Tamil Nadu model has been possible due to the coming together of both government and private hospitals, NGOs and the State Health department. Most of the deceased donation programmes have been developed in southern states of India. The various such programmes are as follows-

National Organ and Tissue Transplant Organization (NOTTO) is a National level organization set up under Directorate General of Health Services, Ministry of Health and Family Welfare, Government of India and only official organization.

India is still far away from other countries like Spain, USA, China, Germany, Australia and Brazil who are way ahead when it comes to organ donation. While Spain is leading the cause of organ donation with the highest rate of organ donation (per million populations) at 46.9, USA has 31.96 rates, followed by Australia and Brazil at 20.70 and 16.60 respectively. China, the most populous nation in the world also has a better organ donation rate than India by 03.67. In India the organ donation rate is only 0.5

There is a wide gap between the number of organs required and the organs available. 2 lakh people await kidney transplant, but only 10,000 get one that is only five per cent. 50,000 individuals await heart, but in 2017 , only 339 deceased heart donations were witnessed. ${ }^{(5)}$

The huge gap exists even when an individual can save up to 8 lives.

Over the years, the number of deceased donors has witnessed threefold increase. While in 2013, there were only 313 donors across India, 2014 saw 411 donors and 2017 had 905 cadaver organ donors leading to 2870 organ donation. But still given the demand and size of the population, India remains a country with one of the lowest organ donation rates in the world. 
Uttar Pradesh, the most populous state in the country, which witnessed just seven deceased donors contributing to 19 organs in 2017, followed by Delhi which had 45 donors and 136 organs donated. The present situation of the state is due to the lack of knowledge, socio-cultural conditions, religious taboos etc. The scenario can be improved by educating the public and motivating the younger generation. Hence the researcher felt the need for the study. Survey based on the data collection from the young learners was taken.

\section{STATEMENT OF THE PROBLEM}

A study to assess the effect of structured teaching programme related to importance of organ donation among adults of Lucknow city.

\section{OBJECTIVES OF THE STUDY}

1. To identify existing knowledge related to importance of organ donation.

2. To determine the effect of teaching related to organ donation.

3. To find an association between the level of knowledge of adults and selected demographic variables

\section{METHODOLOGY}

Research Methodology refers to controlled investigations of the ways of obtaining, organizing and analyzing data. It addresses the development, validation and evaluation of research tools or techniques.

\section{Research Approach}

The research method adopted for the present study was evaluative approach as the study aimed at effect of teaching (importance of organ donation) for adults, of selected areas of Lucknow and determining its effectiveness statistically. This approach would help the investigator to evaluate the effect of the specific intervention that is 'effect of structured teaching programme' on the variable that is 'knowledge' of adults on organ donation.

\section{Research Design}

Quasi experimental (one group) pre-test and post-test design.

\section{VARIABLES}

\section{Independent Variable}

The independent variable is structured teaching programme on importance of organ donation.

\section{Dependent Variable}

The dependent variable is knowledge of adults on importance of organ donation.

\section{Setting}

The present study was conducted in Ashiyana area of Lucknow, U.P.

\section{Population}

The population comprises of $25 \%$ teachers, $25 \%$ students, $25 \%$ older adults and $25 \%$ paramedical staff.

\section{Sampling}

Sample size is 100

Sampling Technique

Non probability purposive sampling was adopted

Sampling Criteria

Inclusion Criteria

- Adults who are willing to participate.

- Adults who know to read and write Hindi and English

- Adults above 18 years old

\section{Exclusion Criteria}

- Adults who are illiterate

\section{DEVELOPMENT OF TOOL}

A self-structured questionnaire was developed for assessing the knowledge related to importance of organ donation. For the selection of the items and preparation of the tool the following steps were taken.

Review of research and non-research literature was conducted on organ donation. Opinion and suggestions were taken from experts, which helped in determining the important areas to be included.

\section{DESCRIPTION OF THE TOOL}

The Structured Questionnaire consists of two sections:

Section A:This section is the first section seeking information on demographic background of adults i.e. age of sample, gender, religion educational status, family income, source of information on organ donation, willingness to donate organ and knowledge on organ banks. It consists of total 09 questions.

Section B: This section is the second part of self-structured questionnaire, which consists of questions assessing knowledge about organ donation and comprising of questions on the following. 
1. Awareness about organ donation.

2. Procedure of organ donation.

3. Facts about organ donation.

4. Misconceptions about organ donation.

There are a total of 20 questions in the questionnaire, Item number 1-5 inquire to awareness about organ donation, item number 6-10 related to procedure of organ donation, item number 11-15 regarding facts about organ donation, item number 16-20 clarify the misconceptions of organ donation

\section{SCORING}

There were four options given for the questionnaires. The scoring for correct answer was ' 1 ' and for the wrong answers were ' 0 '. The scores range from a minimum of zero to a maximum score of 20.

The levels of knowledge have been classified as:

- Poor

- Average

- Good

\section{PROCEDURE FOR DATA COLLECTION}

Objectives of the study were discussed and consent for participation in the study was taken from the selected group. The investigator assured the subjects about the confidentiality of the data. The investigator himself administered the self-structured questionnaire for the pre-test. The duration of data collection for each sample was 20 to 25 minutes. The teaching was disseminated to the group after the pre-test and a brief introduction.

The instruction about post-test was given to the participants of experimental group. The post-test was conducted on $7^{\text {th }}$ day respectively after administering structured teaching. Time taken for post-test by each sample was 15 minutes approximately.

\section{RESULTS AND DISCUSSIONS}

The data was analyzed based on the following objectives.

1. To identify existing knowledge on importance of organ donation.

2. To determine the effect of structured teaching programme on organ donation.

3. To find an association between the level of knowledge of adults and selected demographic variables.

\section{ORGANIZATION OF STUDY FINDINGS}

The collected data is tabulated, analyzed, organized and presented under the following headings.

SECTION I: It deals with the analysis of the demographic data of the samples like age, educational status, religion monthly income and occupation.

SECTION II: It deals with the analysis of data related to knowledge scores before and after structured teaching Programme.

SECTION III It includes analysis of data related to effectiveness of teaching related to organ donation among adults of Lucknow city

SECTION IV: It includes analysis of data to find the association between selected demographic variables such as age, educational status, occupation, and economical status.

The data presented in table 1 shows that in the experimental group of the study, majority (37\%) of the adults fall in the age group of $18-27$ Years,15\% fall in the category of $28-37$ years, $13 \%$ in the age group of $38-47$ years and the least $(10 \%)$ fall in the category of $48-57$ years and $25 \%$ are above 58 years age.58\% are male participants and $42 \%$ are female participants. $91 \%$ of participants belong to Hindu religion.

The greater part $(42 \%)$ of adults has an educational status up to $12^{\text {th }}$ standard. The occupation of the participants comprises of $25 \%$ teachers, $25 \%$ students, $25 \%$ paramedical staff, $21 \%$ retired people and $4 \%$ home makers. The demographic data of the study also reveals that $42 \%$ of study participant have no information on importance of organ donation. $27 \%$ have information on organ donation from mass media,13\% got the information from friends and relatives and only $18 \%$ have the information on organ donation from medical people.

The adults willing to pledge their organs were only $37 \%$ before teaching, out of which $13 \%$ were students, $13 \%$ were teachers, $7 \%$ paramedical staff and $4 \%$ senior citizens. After the teaching was given $90 \%$ were willing to donate their organs after death. Majority (90\%) were unaware about organ donation and tissue bank. Information regarding the same is given.

It deals with the analysis of data related to knowledge scores before and after administering structured teaching Programme on importance of organ donation. 
SECTION 1

Table 1: Frequency and percentage of socio demographic characteristics

\begin{tabular}{|c|c|c|c|}
\hline S NO & CHARACTERISTICS & FREQUENCY & PERCENTAGE \\
\hline 1. & $\begin{array}{lc}\text { Age } & \\
1.1 & 18-27 \text { Years } \\
1.2 & 28-37 \text { Years } \\
1.3 & 38-47 \text { Years } \\
1.4 & 48-57 \text { Years } \\
1.5 & 58 \text { Years and above }\end{array}$ & $\begin{array}{l}37 \\
15 \\
13 \\
10 \\
25\end{array}$ & $\begin{array}{l}37 \\
15 \\
13 \\
10 \\
25\end{array}$ \\
\hline 2 & $\begin{array}{ll}\text { Gender } & \\
1.1 & \text { Male } \\
1.2 & \text { Female }\end{array}$ & $\begin{array}{l}58 \\
42\end{array}$ & $\begin{array}{l}58 \\
42\end{array}$ \\
\hline 3 & $\begin{array}{l}\text { Educational status } \\
4.1 \text { Upto } 7^{\text {th }} \text { standard } \\
4.2 \text { Upto } 10^{\text {th }} \text { standard } \\
4.3 \text { Upto } 12^{\text {th }} \text { standard } \\
\text { 4.4 Graduation } \\
\text { 4.5 Post Graduation }\end{array}$ & $\begin{array}{l}02 \\
04 \\
42 \\
22 \\
29\end{array}$ & $\begin{array}{l}02 \\
04 \\
42 \\
22 \\
29\end{array}$ \\
\hline 5 & $\begin{array}{l}\text { Religion } \\
\text { 3.1 Hindu } \\
\text { 3.2 Muslim } \\
\text { 3.3 Christian }\end{array}$ & $\begin{array}{l}91 \\
01 \\
08\end{array}$ & $\begin{array}{l}91 \\
01 \\
08\end{array}$ \\
\hline 6 & \begin{tabular}{ll}
\multicolumn{2}{l}{ Occupation } \\
5.1 & Teacher \\
5.2 & Student \\
5.3 & Paramedical \\
5.4 & Retired \\
$\mathbf{5 . 5}$ & Home maker
\end{tabular} & $\begin{array}{l}25 \\
25 \\
25 \\
21 \\
04\end{array}$ & $\begin{array}{l}25 \\
25 \\
25 \\
21 \\
04\end{array}$ \\
\hline 7 & \begin{tabular}{ll}
\multicolumn{2}{l}{ Monthly family income } \\
6.1 & Below Rs 10,000/ \\
6.2 & Rs $10.000-30,000 /$ \\
6.3 & Above Rs $10,000 /$
\end{tabular} & $\begin{array}{l}27 \\
46 \\
27\end{array}$ & $\begin{array}{l}27 \\
46 \\
27\end{array}$ \\
\hline 8 & \begin{tabular}{ll}
\multicolumn{2}{l}{ Source of information on eye donation } \\
$7.1 \quad$ Mass media. \\
$7.2 \quad$ Friends, Relatives \\
$7.3 \quad$ Medical people. \\
$7.4 \quad$ None
\end{tabular} & $\begin{array}{l}27 \\
13 \\
18 \\
42\end{array}$ & $\begin{array}{l}27 \\
13 \\
18 \\
42\end{array}$ \\
\hline
\end{tabular}

Table 2: Pretest and post test scores of each category of knowledge on organ donation

\begin{tabular}{|c|c|c|c|c|c|c|}
\hline \multirow{2}{*}{$\begin{array}{l}\text { S } \\
\text { No }\end{array}$} & \multirow{2}{*}{ Areas } & \multicolumn{2}{|c|}{ Pre-test knowledge score } & \multicolumn{2}{|c|}{ Post-test knowledge score } & \multirow{2}{*}{$\begin{array}{l}\text { Paired } \\
\text { 't' value }\end{array}$} \\
\hline & & Mean & SD & Mean & SD & \\
\hline 1 & $\begin{array}{c}\text { Knowledge on organ } \\
\text { donation }\end{array}$ & 2.15 & 1.376 & 4.94 & .2564 & -21.147 \\
\hline 2 & $\begin{array}{l}\text { Procedure of organ } \\
\text { donation }\end{array}$ & 1.43 & 1.283 & 4.78 & .427 & -24.273 \\
\hline 3 & $\begin{array}{c}\text { Facts about organ } \\
\text { donation }\end{array}$ & 1.17 & 1.126 & 4.930 & .2564 & -21.047 \\
\hline 4 & $\begin{array}{c}\text { Misconceptions about } \\
\text { organ donation }\end{array}$ & 1.26 & 1.282 & 4.90 & .333 & -23.755 \\
\hline
\end{tabular}


Table No: 2 shows that Pre-treatment knowledge regarding knowledge on organ donation, Procedure of organ donation Facts about organ donation Misconceptions about organ donation the average score has been improved after administering structured teaching. Researcher applied paired t test in each. Since $p$ value is less than 0.05 ( $p$ value $=0.000$ ) with 99 degrees of freedom at $5 \%$ level of significance there is significant rise in average knowledge score regarding each section related to importance of organ donation.

\section{SECTION -III}

This section deals with the pretest scores and post test scores and thereby assessing the effect of teaching on importance of organ donation.

There were 100 samples taken for study. Each of them has to answer 20 questions. Their pre and post-test correct answers were recorded and mean and standard deviation of the test scores are obtained as below:

Table 3: Pre-test and post-test knowledge score

$\mathrm{N}=\mathbf{1 0 0}$

\begin{tabular}{|c|c|c|c|c|c|}
\hline Phase & Mean Score & S.D. & $\begin{array}{c}\text { Paired ' } \mathrm{t} \text { ' } \\
\text { test }\end{array}$ & Df & P value \\
\hline Pre-test & 6.71 & 3.642 & \multirow[b]{2}{*}{-29.967} & \multirow[b]{2}{*}{99} & \multirow[b]{2}{*}{.001} \\
\hline Post-test & 19.05 & .757 & & & \\
\hline
\end{tabular}

It has been observed that pretreatment knowledge average score is 6.71 and after teaching average knowledge score rises to 19.05 . To check whether this rise in average knowledge score is statistically significant or not, researcher applied paired t test. Since $p$ value is less than 0.05 ( $p$ value $=0.001$ ) there is significant difference in average knowledge score after teaching Programme. Researcher can conclude that at $5 \%$ level of significance there is significant rise in average knowledge score after teaching. This indicates that structured teaching is effective in increasing the knowledge of the samples related to importance of organ donation.

Hence $\mathrm{Ho}$ is rejected and $\mathrm{H} 1$ is accepted

SECTION- IV

This section deals with the association of knowledge score related to importance of organ donation with demographic variables like age, education, religion, gender, occupation, monthly family income.

TABLE 4: Analysis of data to find relationship between knowledge Score and variables

\begin{tabular}{|c|c|c|c|c|}
\hline S. No & Variables & F value & p value & Results \\
\hline 1. & Age of adults & .894 & .471 & No association \\
\hline 2. & Education Status & .682 & .606 & No association \\
\hline 3. & Occupation & .236 & .301 & No association \\
\hline 4. & Income & .231 & .794 & No association \\
\hline 5 & Religion & .254 & .858 & association \\
\hline
\end{tabular}

Since all the $p$ values are $>0.05$ there is no significant association between any of the variables.

\section{CONCLUSION}

The main reasons for organ shortage in India are mainly ignorance and lack of knowledge. People are not well informed enough about the benefits of organ donation.

The organ donation decision is a complex one, based strongly on personal beliefs. There are some factors, such as religious and cultural beliefs, that are seemingly intractable and are often cited as reasons for a refusal to donate. 


\section{REFERENCES:}

1. SaidiRF, HejaziiKenari SK. Challenges of organ shortage for transplantation, solutions and opportunities Int. Journal Organ Transplant. [2014.5:87-96]

2. Kaur S, Ghai S, Krishnan $\mathrm{N}$ et al.Knowlege attitude and perception regarding organ donation among the nursing students. Journal post graduate medical research [2015:49:105-110]

3. BalwaniMr, GumbarMr, et al. Attitude and awareness towards organ donation of India journal of medicine and surgery [2015, 37:582-588]

4. VijaylaxmiPoreddi, Katyani Bb. Attitude knowledge and willingness to donate organs among Indian nursing students. Indian journal of medicine. [2016.27:5 129-138]

5. Tamulli RP, Samulli RP, Sakikia B. Organ donation and attitude and awareness among undergraduates and post graduates of India. Family medicine and primary care. [2019.8.1 130-136] 